\title{
SPECTROPHOTOMETRIC AND SPECTRO- FLUORIMETRIC DETERMINATION OF CERTAIN DIURETICS IN PURE FORMS AND IN THEIR PHARMACEUTICAL FORMULATIONS
}

Michael E. El-Kommos ${ }^{1}$, Ahmad A. Ahmad ${ }^{2}$, Hesham Salem ${ }^{3 *}$ and Mahmoud A. Omar ${ }^{3}$

${ }^{1}$ Department of Pharmaceutical Analytical Chemistry, Faculty of Pharmacy, Assiut University, Assiut, Egypt

${ }^{2}$ Department of Organic Chemistry, Faculty of Science, Minia University, Minia, Egypt

${ }^{3}$ Department of Analytical Chemistry, Faculty of Pharmacy, Minia University, Minia, Egypt

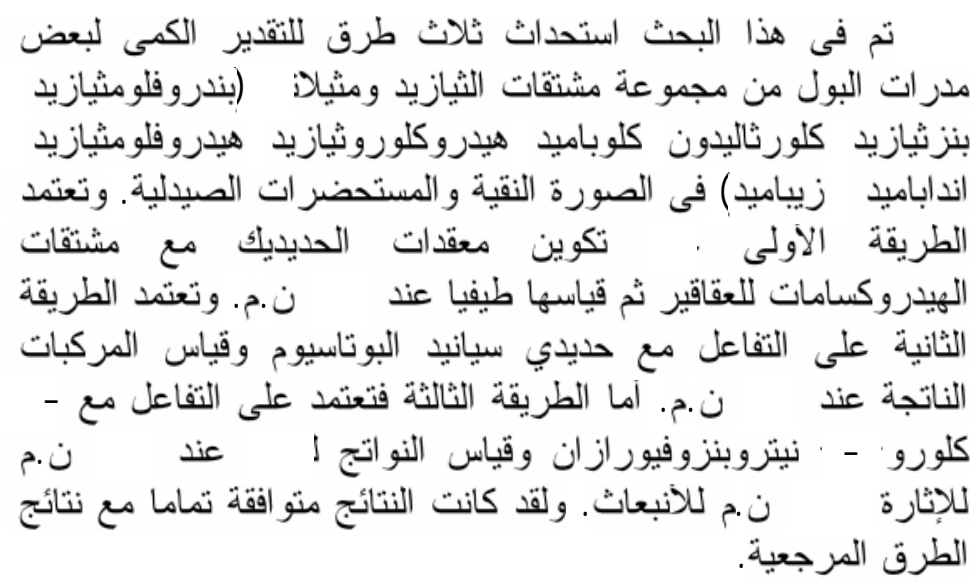

Three Simple and selective spectrophotometric and spectrofluorimetric methods were developed for the quantitative determination of certain diuretics (bendroflumethiazide, benzthiazide, chlorthalidone, clopamide, hydrochlorothiazide, hydroflumethiazide, indapamide and xipamide) in pure forms as well as in their pharmaceutical formulations through their hydroxamate formation and subsequent complexation with iron (method I), reaction with potassium ferricyanide (method II) and

Received in 11/9/2005 \& Accepted in 12/3/2006

"Corresponding author E-mail address: h_salem_eg@yahoo.com 
reaction with 4-chloro-7-nitrobenzofurazan (method III). The conditions for different reactions were studied and optimized. The methods have been validated and successfully applied to the analysis of bulk drugs and their tablets with good recoveries ranging from $97.93( \pm 1.46)$ to $100.6( \pm 1.75)$ for method I, 98.49 $( \pm 1.43)$ to $99.86( \pm 0.87)$ for method II, and $98.98( \pm 1.11)$ to 99.90 $( \pm 0.86)$ for method III. No interference was observed from common pharmaceutical adjuvants. The results obtained compare well with those of reported methods.

\section{INTRODUCTION}

Thiazide diuretics are a major class of diuretic agents that have been used for over 30 years. ${ }^{1}$

Subsequently, drugs that are pharmacologically similar to thiazide diuretics but are not thiazides were developed and are called thiazide-like diuretics. ${ }^{2 \& 3}$

Many analytical procedures have been reported for the determination of the investigated drugs. The British Pharmacopoeia 1998 adopted an electrochemical method for the analysis of the studied drugs. ${ }^{4}$ United States Pharmacopoeia USP XXV, NFXX describes titremetric, spectrophotometric and high performance liquid chromatographic methods for the analysis of the studied drugs. ${ }^{5}$

Bendroflumethiazide has been assayed by chromatographic, ${ }^{6-10}$ spectrophotometric ${ }^{11-13}$ and fluorimetric $^{14 \& 15}$ methods. Benzthiazide has been assayed by chromatographic, ${ }^{16 \& 17}$ spectrophotometric ${ }^{18}$ and electrochemical ${ }^{19}$ methods. Chromatographic ${ }^{20 \& 21}$ and spectrophotometric $^{22}$ methods have been used for assay of chlorthalidone. The most recent methods for determination of clopamide include chromatographic ${ }^{23-25}$ and spectrophotometric ${ }^{26}$ methods. Hydrochlorothiazide has been assayed by chromatographic, ${ }^{27 \& 28}$ spectrophotometric $^{29 \& 30}$ and spectrofluorimetric ${ }^{31}$ methods. Hydroflumethiazide has been assayed by chromatographic $^{32 \& 33}$ and spectrophotometric ${ }^{34 \& 35}$ methods. The most recent methods for determination of indapamide include chromatographic, ${ }^{36-38}$ spectrophotometric ${ }^{39 \& 40}$ and fluorimetric ${ }^{4 \& 42}$ methods. Xipamide has been assayed by chromatographic $\mathrm{c}^{43-45}$ and spectrophotometric ${ }^{46}$ methods.

In continuation, we wish here to develop simple and rapid spectrophotometric and spectrofluorimetric procedures for the determination of thiazide and thiazide-like diuretics suitable for quality control purposes. The structures of the studied drugs are given in Tables 1 and 2 . 
Table 1: The investigated thiazide diuretics.

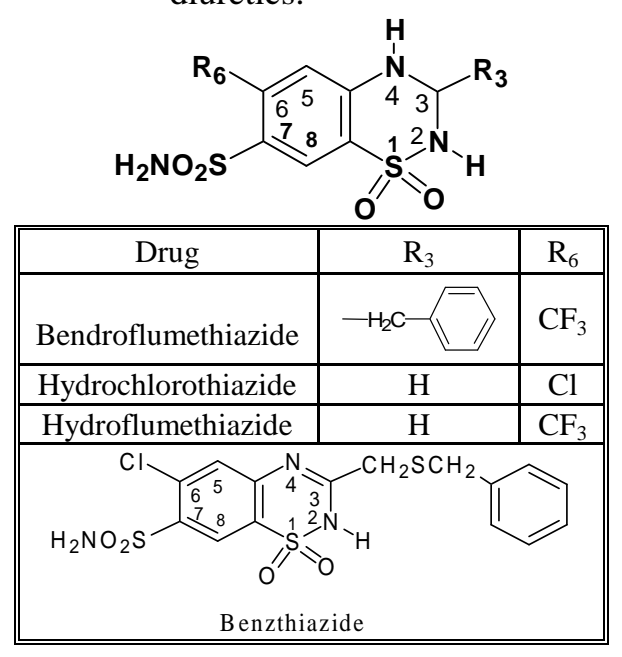

Table 2: The investigated thiazidelike diuretics.<smiles>[R6]c1cc(S(N)(=O)=O)c(Cl)cc1Br</smiles>

\begin{tabular}{|l|l|l|}
\hline \multicolumn{1}{|c|}{ Drug } & $\mathrm{R}_{1}$ & \\
\hline $\begin{array}{l}\text { Chlor- } \\
\text { thalidone }\end{array}$ & $\mathrm{N}$ \\
\hline $\begin{array}{l}\text { Clopa- } \\
\text { mide } \\
\text { Indapa- } \\
\text { mide }\end{array}$ & $\mathrm{O}$ & \\
\hline $\begin{array}{l}\text { Xipa- } \\
\text { mide }\end{array}$ & $\mathrm{OH}$ \\
\hline
\end{tabular}

EXPERIMENTAL

\section{Apparatus}

A Perken Elmer UV-VIS

Spectrophotometer (Tokyo,Japan) with $1 \mathrm{~cm}$ quartz cells was used. Perkin Elmer ${ }^{\mathrm{TM}}$ luminescence spectrometer model LS 45 (Perkin Elmer instruments, USA) connected to an IBM computer loaded with the FLwinlab $^{\text {TM }}$ application software 4.00.02 version was used.

All calculations were carried out on IBM computer using statistical methods in analytical chemistry (SMAC) program, designed by Meier and Zund. ${ }^{47}$

\section{Materials and reagents}

Hydroxylamine hydrochloride $17.25 \mathrm{~g} / 100 \mathrm{~mL}$ in distilled water $(2.5$ M) and Potassium ferricyanide $297.74 \mathrm{mg} / 100 \mathrm{~mL}$ in distilled water (0.01 M). (Loba Chemi Mumbai, India). Sodium hydroxide 32g/100 $\mathrm{mL}$ in distilled water $(8.0 \mathrm{M})$, hydrochloric acid $70.4 \mathrm{~mL} / 100 \mathrm{~mL}$ in distilled water $(8.0 \mathrm{M})$, ferric chloride hexahydrate $14 \mathrm{~g} / 100 \mathrm{~mL}(0.1 \mathrm{M})$, in hydrochloric acid $(0.5 \mathrm{M})$, methanol, ethanol, sodium carbonate, sodium dihydrogen phosphate, disodium hydrogen phosphate, perchloric acid, sulphuric acid, nitric acid, dimethylformamide, dimethylsulfoxide, sodium acetate, phosphoric, boric and citric acids (El-Nasr Co. for pharmaceutical chemicals, Egypt) and 4-chloro-7-nitrobenzofurazan (NBDCl) $100 \mathrm{mg} / 100 \mathrm{~mL}$ in ethanol and 7,7,8,8,-tetracyanoquinodimethane (Sigma Chemical Co., St. Louis, MO, USA). 
Pharmaceutical formulations

Blokium-Diu $^{\circledR}$ tablets (medical

Union Pharmaceutical Co., Abu

Sultan-Ismailia, Egypt), labeled to contain atenolol (100 $\mathrm{mg})$ and chlorthalidone $(25 \mathrm{mg})$ per tablet. Brinerdine ${ }^{\circledR}$ tablets (Novartis Pharma S.A.E. Cairo, Egypt) [under licence from Novartis Pharma AG., Basle, Switzerland], labeled to contain reserpine $(0.1 \mathrm{mg})$, clopamide $(5 \mathrm{mg})$ and dihydroergocristine $(0.5 \mathrm{mg})$ per tablet. Capozide $^{\circledR}$ tablets (Bristol Myers-Squibb Pharmaceutical Co., Cairo, Egypt), labeled to contain captopril $\quad\left(\begin{array}{lll}50 & \mathrm{mg}\end{array}\right)$ and hydrochlorothiazide $(25 \mathrm{mg})$ per tablet. Diurex $^{\circledR}$ tablets (Amriya Pharmaceutical Co., Alexandria, Egypt), labeled to contain indapamide $(2.5 \mathrm{mg})$ per tablet. Epilacton $\mathrm{X}^{\circledR}$ tablets (Egyptian Pharmaceutical Industries Co. [Epico], Tenth of ramadan city, Egypt), labeled to contain xipamide $(20 \mathrm{mg})$ and spironolactone $(100 \mathrm{mg})$ per tablet.

\section{Standard solutions \\ For procedure I}

Weigh accurately $20 \mathrm{mg}$ of each drug, dissolve in $4.0 \mathrm{ml}$ methanol in a 50 -mL volumetric flask and complete to volume with distilled water. This stock solution $(0.4 \mathrm{mg} / \mathrm{mL})$ is diluted to contain $0.04 \mathrm{mglmL}$ (in case of chlorthalidone), $0.08 \mathrm{mg} / \mathrm{mL}$ (in case of clopamide, hydroflumethiazide and xipamide) or $0.16 \mathrm{mg} / \mathrm{mL}$ (in case of benzthiazide, bendroflumethiazide, hydrochlorothiazide and indapamide).

\section{For procedure II}

Weigh accurately $20.0 \mathrm{mg}$ of each drug, dissolve in $4.0 \mathrm{~mL}$ methanol in a 100-mL volumetric flask and complete to volume with distilled water $(0.2 \mathrm{mg} / \mathrm{mL})$.

\section{For procedure III}

Weigh accurately $20.0 \mathrm{mg}$ of bendroflumethiazide, hydrochlorothiazide and hydroflumethiazide or $40.0 \mathrm{mg}$ of clopamide. Dissolve in about $10.0 \mathrm{~mL}$ absolute ethanol in $100-\mathrm{mL}$ volumetric flask and complete to the mark with the same solvent.

\section{Procedures \\ Procedure I \\ Pure drugs}

Accurately measure $1.0 \mathrm{~mL}$ of the standard stock solution $(0.4 \mathrm{mg} / \mathrm{mL})$ into a test tube, add $1.0 \mathrm{~mL}$ of hydroxylamine hydrochloride and 2.0 $\mathrm{mL}$ of sodium hydroxide, heat for 20 minutes in a boiling water bath, cool, transfer into $10-\mathrm{mL}$ volumetric flask, wash the test tube two times with portions of distilled water each of 1 $\mathrm{mL}$ and transfer the washings into the volumetric flask. Add $2.0 \mathrm{~mL}$ of hydrochloric acid and $1.0 \mathrm{ml}$ of ferric chloride hexahydrate. Allow to stand for 20 minutes at room temperature $\left(25 \pm 5^{\circ}\right)$, then dilute with distilled water to volume and mix well. Measure the absorbance at $500 \mathrm{~nm}$ against reagent blank treated similarly. 


\section{Construction of calibration graphs}

Dilute the standard stock solution $(0.4 \mathrm{mg} / \mathrm{mL})$ quantitatively to give a series of concentrations, suitable for constructing the calibration graphs (final drug concentration; 0.3-4 $\mathrm{g} / \mathrm{mL}$ ). Use $1.0 \mathrm{~mL}$ of each solution for the reaction with hydroxylamine and ferric chloride as directed under the procedure for pure drugs.

\section{Stoichiometry}

The stoichiometric ratios were determined by Job's method of continuous variation. ${ }^{48}$ The stability constants for formed chelates were calculated. Stability indicating properties of the assay as well as spectroscopic investigation of the products using IR and ${ }^{1} \mathrm{H}-\mathrm{NMR}$ spectroscopy were studied.

\section{Procedure II Pure drugs}

Accurately measure $1.0 \mathrm{~mL}$ of the standard stock solution $(0.2 \mathrm{mg} / \mathrm{mL})$ into test tube, add $1.0 \mathrm{~mL}$ of sodium hydroxide and $1.0 \mathrm{~mL}$ of potassium ferricyanide, boil for 45 minutes in water bath, cool and transfer into 10$\mathrm{mL}$ volumetric flask. Wash the test tube two times with portions of distilled water each of $1 \mathrm{~mL}$ and transfer the washings into the volumetric flask. Add $1.0 \mathrm{~mL}$ of hydrochloric acid, allow to stand for 20 minutes at room temperature $(25 \pm$ $5^{\circ}$ ), then dilute with distilled water to the volume and mix well. Measure the absorbance at $720 \mathrm{~nm}$ against reagent blank treated similarly.

\section{Construction of calibration graphs}

Dilute the standard stock solution $(0.2 \mathrm{mg} / \mathrm{mL})$ quantitatively to give a series of concentrations, suitable for constructing the calibration graphs (final drug concentration; 2-20 $\mathrm{g} / \mathrm{mL})$. Use $1.0 \mathrm{~mL}$ of each solution for the reaction with potassium ferricyanide as directed under the general analytical procedure.

\section{Stoichiometry}

The stoichiometric ratios were determined by Job's method of continuous variation. ${ }^{48}$

\section{Procedure III \\ Pure drugs}

Accurately measure $1.0 \mathrm{~mL}$ of the standard solution into test tube, add $1.0 \mathrm{~mL}$ of 4-chloro-7-nitrobenzofurazan, heat to $60^{\circ}$ for 45 minute in water bath, cool, transfer into $10-\mathrm{mL}$ volumetric flask, then dilute with ethanol to the volume and mix well. The relative fluorescence intensities of the resulting solutions were measured at room temperature $(25 \pm$ $5^{\circ}$ ) against a reagent blank treated similarly at (excitation $\lambda_{\max } 470 \mathrm{~nm}$ and emission $\lambda_{\max } 535 \mathrm{~nm}$ ).

\section{Construction of calibration graphs}

Dilute the standard stock solution quantitatively to give a series of concentrations suitable for constructing the calibration graphs (2$12 \mathrm{~g} / \mathrm{mL}$ ). Use $1.0 \mathrm{~mL}$ of each solution for the reaction with 4chloro-7-nitrobenzofurazan as directed under the general analytical procedure. 


\section{Stoichiometry}

The stoichiometric ratios were determined by Job's method of continuous variation. ${ }^{48}$

\section{Analysis of pharmaceutical formulations}

Transfer an accurately weighed amount equivalent to $50.0 \mathrm{mg}$ of each drug from composite of 20 powdered tablets into a $100-\mathrm{mL}$ calibrated flask. Dissolve and dilute to the mark with distilled water, sonicate for 10 minutes and filter off to obtain a solution of $1.0 \mathrm{mg} / \mathrm{mL}$. Further dilutions with distilled water were made to obtain sample solutions, then the general procedures I, II and III were followed.

\section{RESULTS AND DISCUSSION}

\section{Method I}

The interaction of the hydroxamic acid derivatives of all studied drugs, bendroflumethiazide, benzthiazide, chlorthalidone, clopamide, hydrochlorothiazide, hydroflumethiazide, indapamide and xipamide with ferric chloride hexahydrate, in acidic medium gave a red coloured product with an absorption maximum at 500 $\mathrm{nm}$. The absorption spectrum of the interaction product of ferric chloride hexahydrate with xipamide hydroxamate as a representative example for the studied drugs is shown in Figure 1.
Factors affecting color development

A preliminary investigation was carried out to determine the optimumconditions for the hydroxamate formation and subsequent chelate formation for the studied drugs.

\section{Effect of hydroxylamine concent- ration}

The absorption intensity of the resulting ferric chelate was found to increase by increasing concentration of hydroxylamine and reaches its maximum value at $1.0 \mathrm{~mL}$ of $2.5 \mathrm{M}$ per $10 \mathrm{~mL}$ of final solution, after which no further increase was noticed (Fig. 2).

\section{Effect of sodium hydroxide concentration}

The absorption intensity of the resulting ferric chelate was found to increase by increasing concentration of sodium hydroxide and reaches its maximum value at $1.0 \mathrm{~mL}$ of $8.0 \mathrm{M}$ per $10 \mathrm{~mL}$ of final solution, after which no further increase was noticed. Higher concentrations are not recommended to avoid addition of more hydrochloric acid because the reaction was performed in acidic medium (Fig. 3).

\section{Effect of temperature}

The intensity of absorption of the resulting ferric chelates increases on increasing temperature upon interaction of the drugs with hydroxylamine and sodium hydroxide to form hydroxamic acids, the best 
results were obtained at boiling point $\left(100^{\circ}\right)$.

\section{Effect of time of boiling}

The intensity of absorption of the resulting ferric chelates increases on increasing time of heating the drug with hydroxylamine and sodium hydroxide to form hydroxamic acid. Optimum reaction time was attained after 20 minutes for all the studied drugs (Fig. 4).

\section{Effect of hydrochloric acid concentration}

The absorption intensity of the resulting ferric chelates increases by increasing concentration of hydrochloric acid and reaches its maximum value at $1.0 \mathrm{~mL}$ of $8.0 \mathrm{M}$ per $10 \mathrm{~mL}$ of final solution, after which the absorption intensity decreases (Fig. 5).

\section{Effect of ferric chloride concent-} ration

The absorption intensity of the resulting ferric chelate increases by increasing concentration of ferric chloride and reaches its maximum value at $1.0 \mathrm{~mL}$ of $0.5 \mathrm{M}$ per $10 \mathrm{~mL}$ of final solution, after which no further increase was noticed. Higher concentrations are not recommended to avoid high absorption intensity of the reagent blank (Fig. 6).

\section{Effect of chelate development time}

The optimum chelation reaction time was determined by following the colour development at room temperature $\left(25 \pm 5^{\circ}\right)$ at $500 \mathrm{~nm}$. The reaction of ferric chloride with each of the hydroxamate of the studied drugs exhibits higher colour intensity when the reaction mixture was diluted to the volume directly before measurement. Optimum reaction time was attained after 20 minutes for all the studied drugs and the colour remained stable for further 15 minutes for all the studied drugs (Fig. 7).

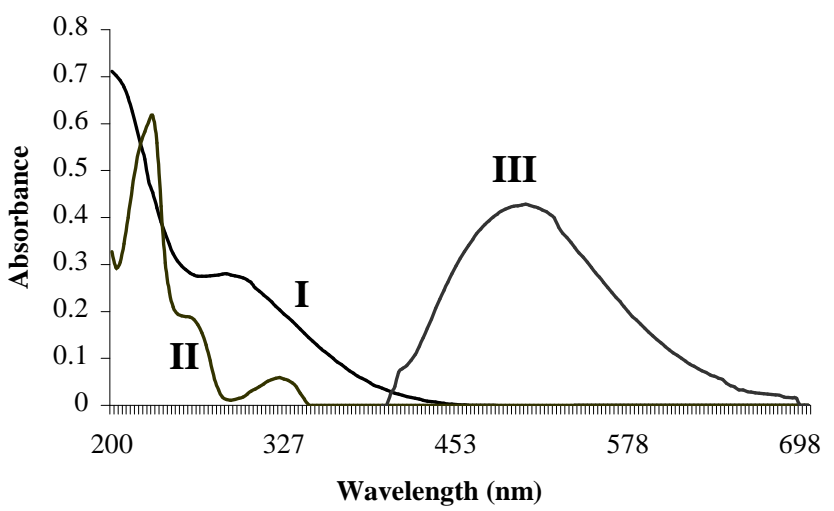

Fig. 1: Absorption spectra of $6 \mu \mathrm{g} / \mathrm{mL}$ ferric chloride (I), $4 \mu \mathrm{g} / \mathrm{mL}$ xipamide (II) and $0.8 \mu \mathrm{g} / \mathrm{mL}$ resulting ferric hydroxamate of xipamide (III). 


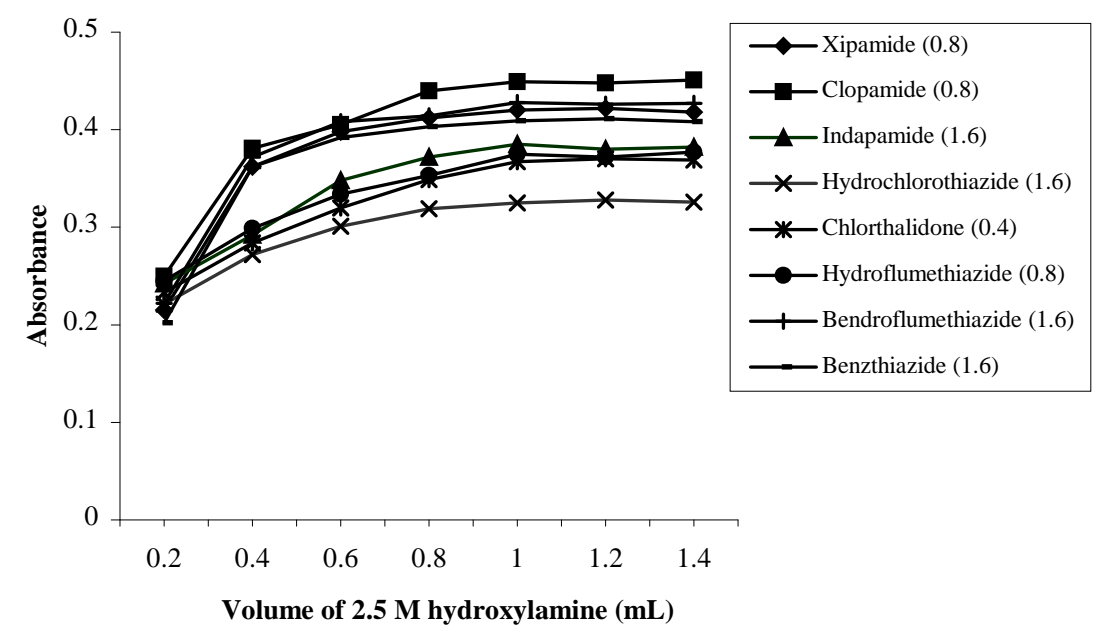

Fig. 2: Effect of hydroxylamine concentration on the formation of the hydroxamate derivatives of investigated drugs $(\mu \mathrm{g} / \mathrm{ml})$.

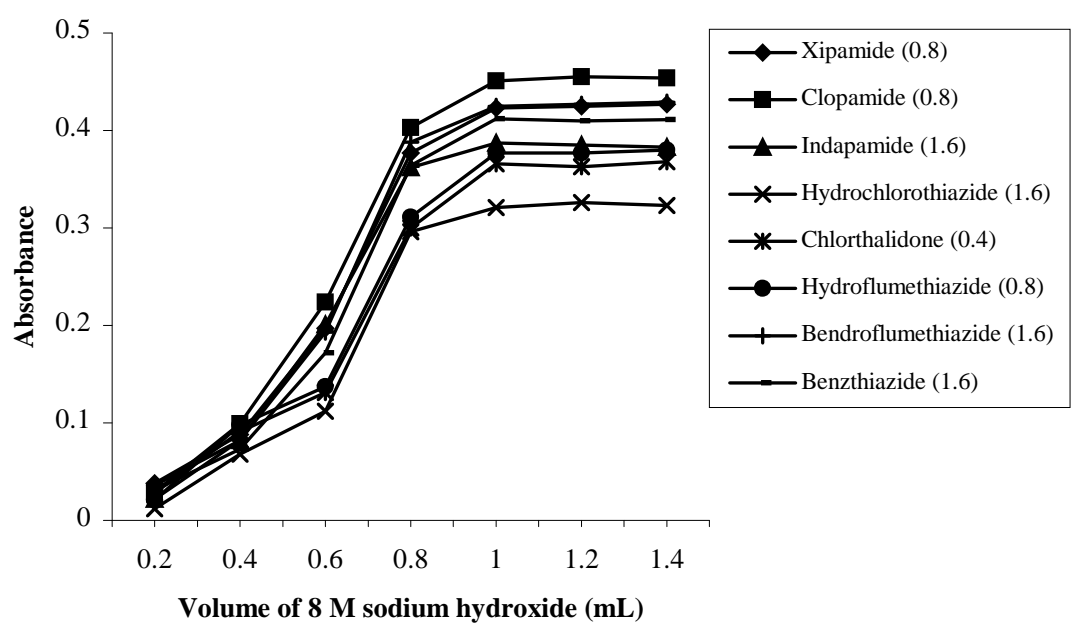

Fig. 3: Effect of sodium hydroxide concentration on the formation of the hydroxyamate derivatives of investigated drugs $(\mu \mathrm{g} / \mathrm{ml})$. 


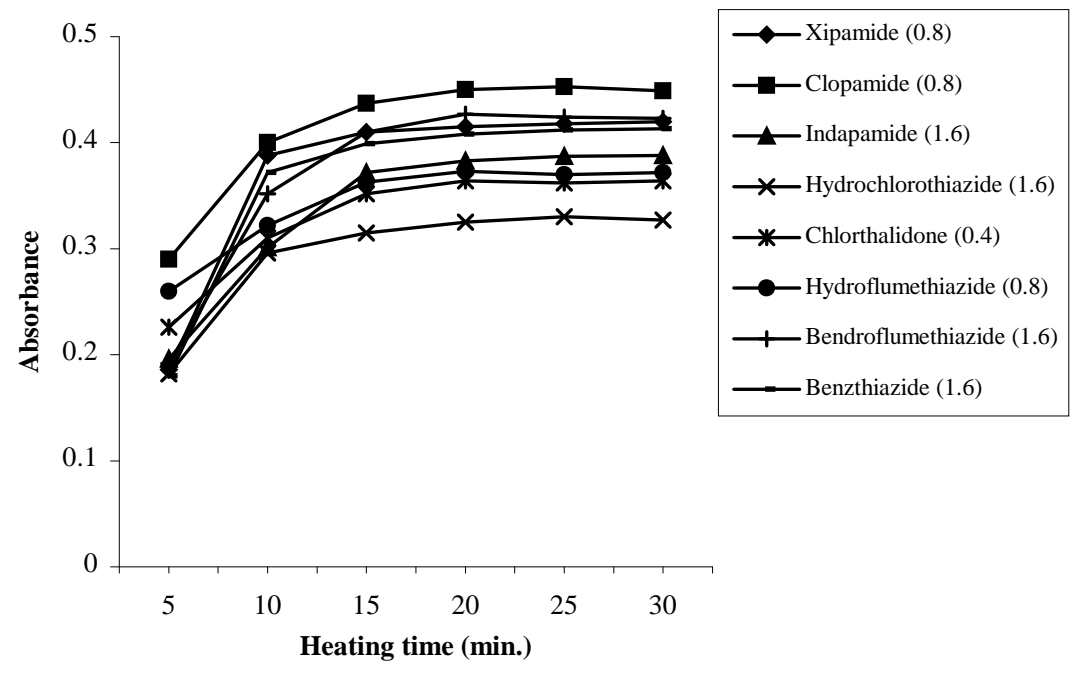

Fig. 4: Effect of heating time on the reaction between the investigated drugs $(\mu \mathrm{g} / \mathrm{ml})$ and hydroxylamine.

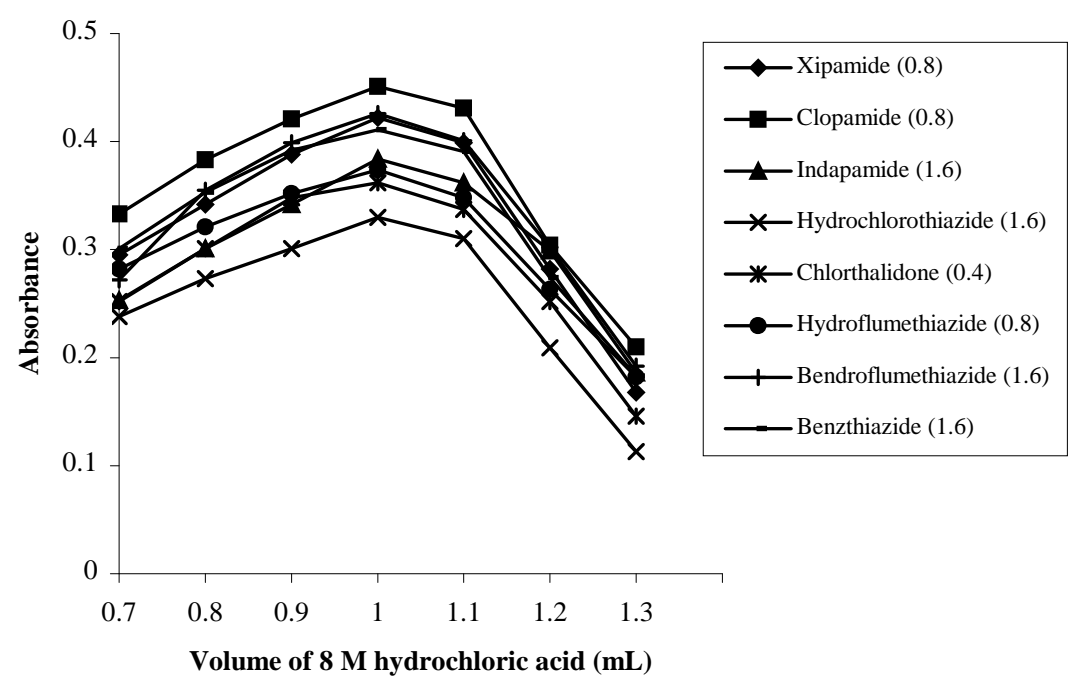

Fig. 5: Effect of hydrochloric acid concentration on the reaction between the hydroxyamates of investigated drugs $(\mu \mathrm{g} / \mathrm{ml})$ and ferric chloride reagent. 


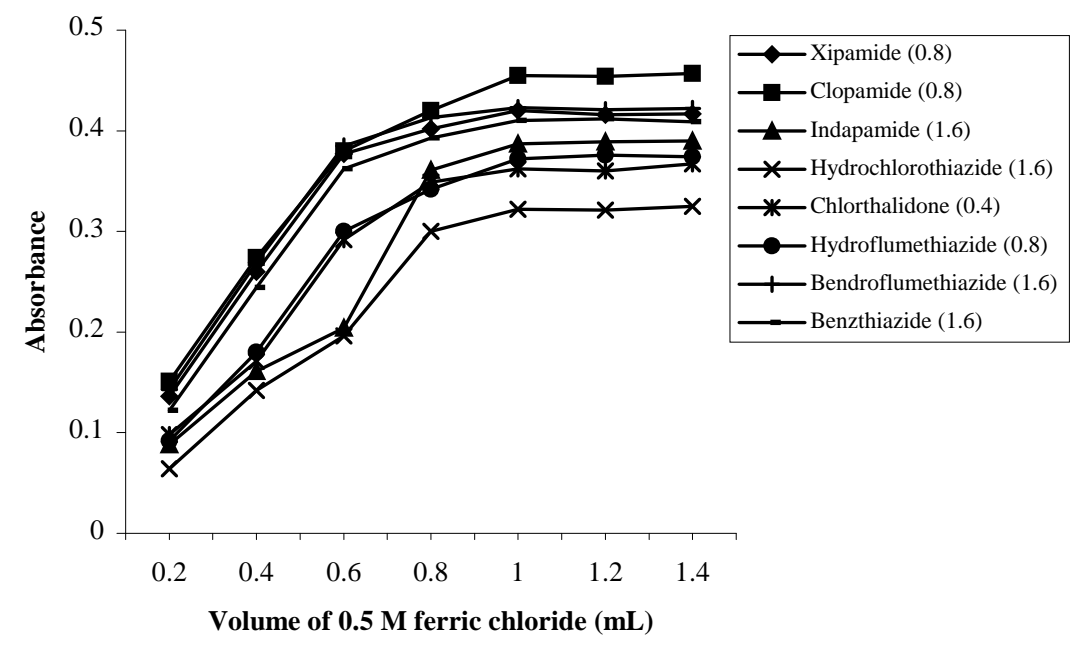

Fig. 6: Effect of ferric chloride concentration on the reaction between the hydroxamates of investigated drugs $(\mu \mathrm{g} / \mathrm{ml})$ and ferric chloride reagent.

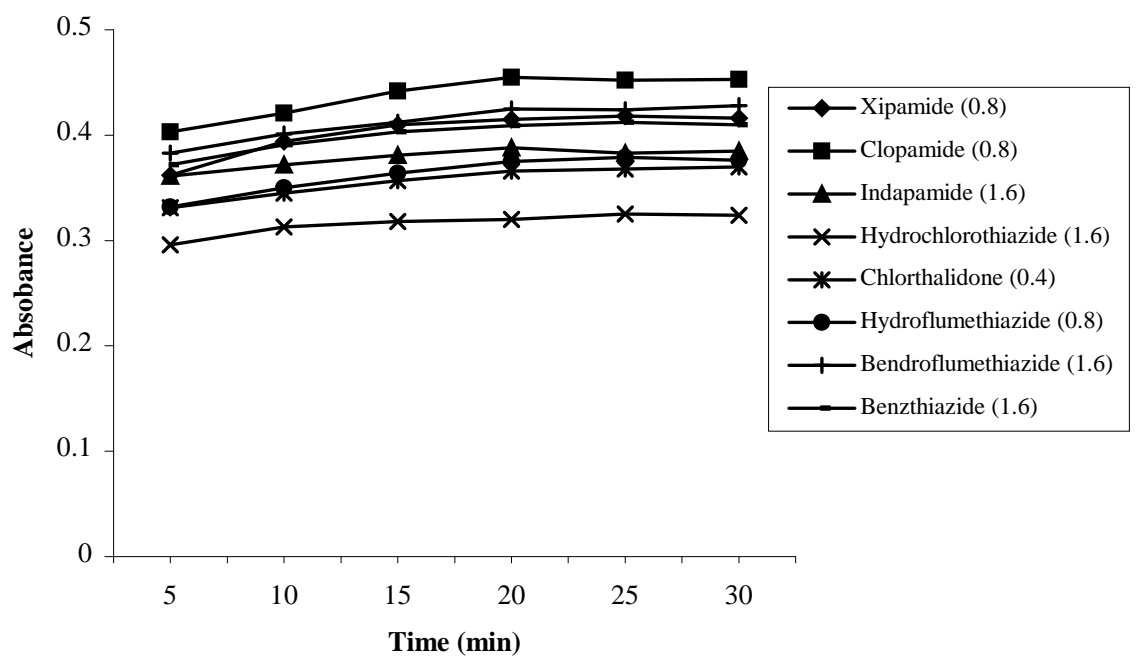

Fig. 7: Effect of reaction time of the hydroxamates of investigated drugs $(\mu \mathrm{g} / \mathrm{ml})$ with ferric chloride reagent. 


\section{Quantitative parameters}

The regression equations were derived using the least-squares method. The intercepts (a), slopes (b), correlation coeffecients (r), limits of detection (LOD) and limits of quantitation (LOQ) were calculated. The slopes are used as a measure of the sensitivity of the proposed method, while the intercepts are used as a measure of the interfering background, (Table 3). Results indicate high sensitivity and low background effect in ferric hydroxamate method.

\section{Stoichiometric study}

Using job's method of continuous variation, the molar ratio of ferric chloride to each of the hydroxamates of investigated drugs was 1:3.

\section{Determination of stability constant}

The stability constants of the ferric hydroxamates of investigated drugs were calculated using the following equation. ${ }^{49}$

$$
\begin{gathered}
\left.\mathrm{K}_{\mathrm{s}}=\left(\mathrm{A} / \mathrm{A}_{\mathrm{ex}} \mathrm{C}_{\mathrm{x}}\right) / \mathrm{C}_{\mathrm{M}}-\mathrm{A} / \mathrm{A}_{\mathrm{ex}} \mathrm{C}_{\mathrm{x}}\right) \\
\left(\mathrm{C}_{\mathrm{L}}-\mathrm{nA} / \mathrm{A}_{\mathrm{ex}} \mathrm{C}_{\mathrm{x}}\right)^{\mathrm{n}}
\end{gathered}
$$

Where: $K_{s}$ is the stability constant of the formed product. $\mathrm{N}=\mathrm{X} /(1-\mathrm{X})$ where $\mathrm{X}$ is the mole fraction of the ligand at the maximum of the continuous variation curve. $\mathrm{A} / \mathrm{A}_{\mathrm{ex}}$ is the ratio of the observed absorption to that indicated by the tangent for the same wavelength. $C_{M}$ is the molar concentration of the metal. $\mathrm{C}_{\mathrm{L}}$ is the molar concentrations of the ligand. $\mathrm{C}_{\mathrm{x}}$ $=\mathrm{C}_{\mathrm{L}} / \mathrm{n}$. The calculated stability constants for the formed ferric hydroxamates of the investigated drugs ranged from $6.8 \times 10^{6}$ to $27.1 \times$ $10^{6}$ indicating good stability of the studied chelates. The high stability constants of the formed products may account for their high absorption intensity. The calculated stability constants are in good correlation with the measured absorption intensities of the studied products.

\section{Effect of excipients}

The assay results obtained by the proposed method were unaffected by the presence of commonly used excipients. No interference was observed from exipients such as starch, talc, sucrose and magnesium stearate.

\section{Suggested reaction mechanism}

The mechanism of reaction is thus based on the interaction between the sulphamoyl group of the chosen drug and hydroxylamine hydrochloride in alkaline medium to form corresponding hyroxamate and subsequent chelation of the resulting hydroxamates with iron (III) ions in acid medium to give red coloured products. The reaction mechanism should be suggested depending on the obtained molar ratio and previous reports, Scheme I.

\section{Analysis of pharmaceutical dosage forms}

The obtained high intensity absorption bands and the very low background make this method suitable for the routine quality control analysis of the investigated compounds with no interference from common additives. The proposed and 
Table 3: Spectral characteristics, Beer's law data, and statistical analysis for the proposed methods.

\begin{tabular}{|c|c|c|c|c|c|c|c|}
\hline Drug & Procedure & $\begin{array}{l}\text { Linear } \\
\text { range, } \\
\mu \mathrm{g} / \mathrm{ml}\end{array}$ & A & b & $\mathrm{r}$ & $\begin{array}{r}\text { LOD } \\
\mu \mathrm{g} / \mathrm{mL}\end{array}$ & $\begin{array}{r}\text { LOQ } \\
\mu \mathrm{g} / \mathrm{mL}\end{array}$ \\
\hline \multirow{2}{*}{ Xipamide } & $\mathrm{I}$ & $0.4-1.6$ & 0.0097 & 1.889 & 0.9999 & 0.013 & 0.026 \\
\hline & II & $6-16$ & 0.0132 & 0.038 & 0.9995 & 0.398 & 1.327 \\
\hline \multirow{3}{*}{$\begin{array}{c}\text { Clopamide } \\
\mathrm{HCl}\end{array}$} & $\bar{I}$ & $0.4-1.6$ & 0.0046 & 1.785 & 0.9998 & 0.019 & 0.038 \\
\hline & II & $2-7$ & 0.0010 & 0.133 & 0.9999 & 0.057 & 0.188 \\
\hline & III & $4-12$ & 0.24 & 3.78 & 0.9999 & 0.217 & 0.430 \\
\hline \multirow{2}{*}{ Indapamide } & $\mathrm{I}$ & $1.2-3.2$ & 0.0931 & 3.985 & 0.9990 & 0.142 & 0.276 \\
\hline & II & $7.5-20$ & 0.0062 & 0.036 & 0.9999 & 0.413 & 1.377 \\
\hline \multirow{3}{*}{$\begin{array}{c}\text { Hydrochloro- } \\
\text { thiazide }\end{array}$} & $\mathrm{I}$ & $1.2-4$ & 0.0135 & 4.961 & 0.9989 & 0.117 & 0.230 \\
\hline & II & $2-7$ & 0.0020 & 0.116 & 0.9998 & 0.125 & 0.417 \\
\hline & III & $2-6$ & 1.06 & 3.38 & 0.9995 & 0.243 & 0.474 \\
\hline \multirow{2}{*}{ Chlorthalidone } & $\mathrm{I}$ & $0.3-0.9$ & 0.0026 & 1.090 & 0.9998 & 0.012 & 0.023 \\
\hline & II & $7.5-20$ & 0.0010 & 0.034 & 0.9997 & 0.415 & 1.385 \\
\hline \multirow{2}{*}{$\begin{array}{c}\text { Hydroflume- } \\
\text { thiazide }\end{array}$} & I & $0.6-1.6$ & 0.0187 & 2.155 & 0.9997 & 0.035 & 0.070 \\
\hline & III & $2-6$ & 0.16 & 6.53 & 0.9990 & 0.329 & 0.634 \\
\hline \multirow{3}{*}{$\begin{array}{c}\text { Bendroflume- } \\
\text { thiazide }\end{array}$} & I & $0.8-3.2$ & 0.0282 & 3.794 & 0.9999 & 0.027 & 0.053 \\
\hline & II & $3-7$ & 0.0018 & 0.075 & 0.9996 & 0.183 & 0.610 \\
\hline & III & $2-6$ & 0.56 & 7.29 & 0.9992 & 0.310 & 0.600 \\
\hline \multirow{2}{*}{ Benzthiazide } & I & $0.8-3.2$ & 0.0149 & 3.814 & 0.9998 & 0.038 & 0.076 \\
\hline & II & $3-8$ & 0.0067 & 0.063 & 0.9996 & 0.207 & 0.690 \\
\hline
\end{tabular}

a, intercept; b, slope; r, correlation coeffecient; LOD, limit of detection; LOQ, limit of quantitation. 


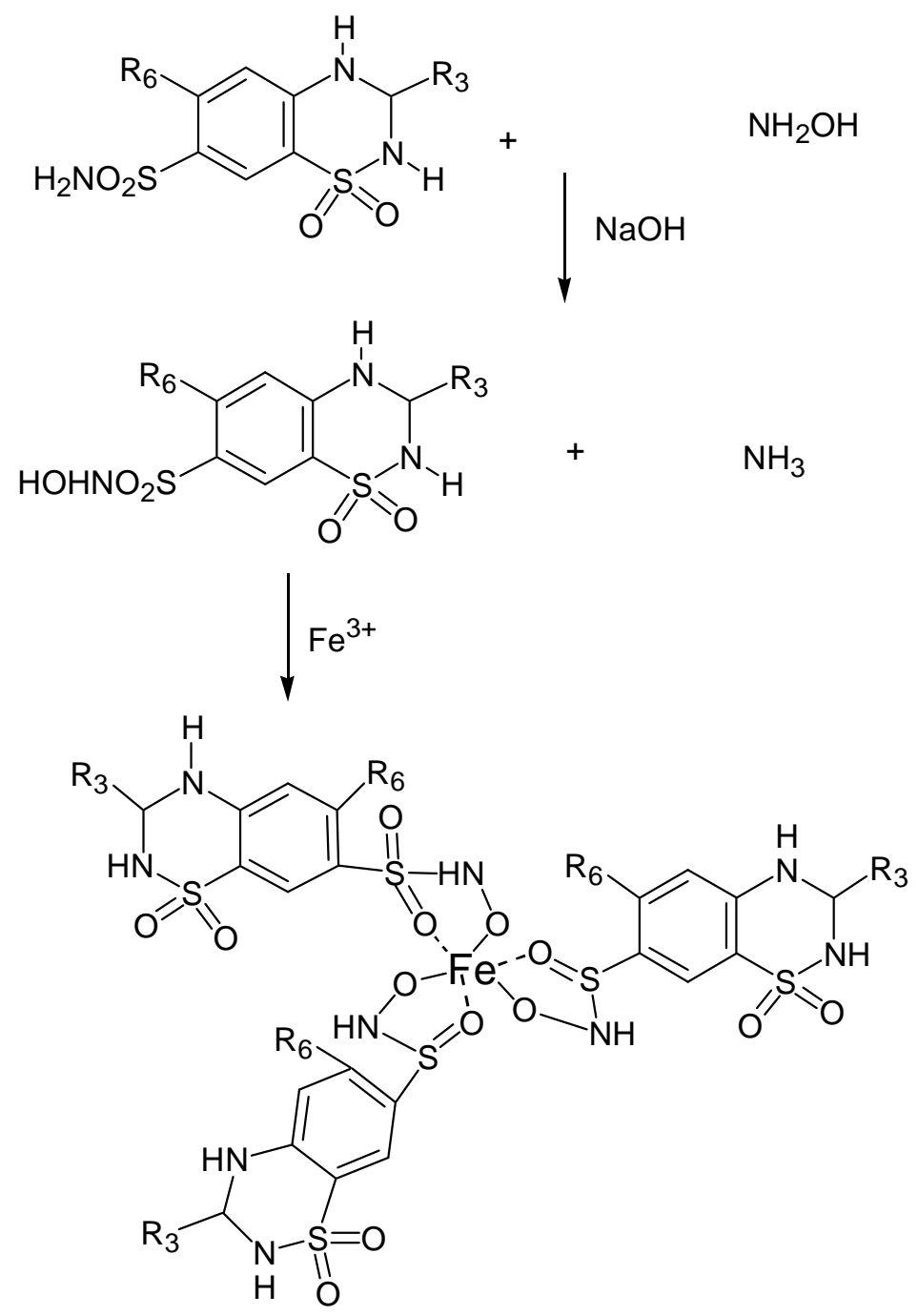

Scheme I: Suggested mechanism for the reaction of studied drugs with hydroxylamine followed by ferric chloride.

reported methods were applied to the determination of the studied drugs in tablets (Table 4). The t- and F-testes showed no significant differences between the calculated and theoretical values ( $95 \%$ confidence) of both the proposed and reported methods. This finding indicates similar precision and accuracy. 
Table 4: Determination of the cited drugs in their pharmaceutical preparations by the proposed and reported methods.

\begin{tabular}{|c|c|c|c|c|c|c|}
\hline Drug & $\begin{array}{c}\text { Parmaceutical } \\
\text { Product } \\
\end{array}$ & Parameters & I & II & III & $\begin{array}{l}\text { Reported } \\
\text { method* }\end{array}$ \\
\hline $\begin{array}{l}\text { Hydrochloro- } \\
\text { thiazide }\end{array}$ & Capozide & $\begin{array}{c}\mathrm{X} \\
\pm \text { S.D }^{\mathrm{a}} \\
\mathrm{t} \\
\mathrm{F}\end{array}$ & $\begin{array}{c}100.6 \\
\pm 1.75 \\
1.28 \\
1.98\end{array}$ & $\begin{array}{c}99.86 \\
\pm 0.87 \\
0.61 \\
2.04 \\
\end{array}$ & $\begin{array}{c}99.90 \\
\pm 0.86 \\
0.72 \\
3.33\end{array}$ & $\begin{array}{l}99.48 \\
\pm 1.25\end{array}$ \\
\hline Chlorthalidone & Blokium Diu & $\begin{array}{c}\text { X } \\
\pm \text { S.D. } \\
\text { t } \\
F\end{array}$ & $\begin{array}{c}98.57 \\
\pm 1.39 \\
0.29 \\
1.42\end{array}$ & $\begin{array}{c}98.49 \\
\pm 1.43 \\
0.19 \\
1.49\end{array}$ & & $\begin{array}{l}98.35 \\
\pm 1.17\end{array}$ \\
\hline Clopamide & Brinerdine & $\begin{array}{c}\mathrm{X} \\
\pm \text { S.D. } \\
\mathrm{t} \\
\mathrm{F} \\
\end{array}$ & $\begin{array}{c}99.81 \\
\pm 1.20 \\
0.75 \\
3.88 \\
\end{array}$ & $\begin{array}{c}99.91 \\
\pm 0.72 \\
1.36 \\
1.14 \\
\end{array}$ & $\begin{array}{c}98.98 \\
\pm 1.11 \\
0.79 \\
3.29 \\
\end{array}$ & $\begin{array}{l}99.39 \\
\pm 0.61\end{array}$ \\
\hline Indapamide & Natrilex & $\begin{array}{c}\text { X } \\
\pm \text { S.D. } \\
\text { t } \\
F \\
\end{array}$ & $\begin{array}{c}97.93 \\
\pm 1.46 \\
0.03 \\
1.29 \\
\end{array}$ & $\begin{array}{c}98.81 \\
\pm 1.46 \\
1.13 \\
1.29 \\
\end{array}$ & & $\begin{array}{l}97.91 \\
\pm 1.29\end{array}$ \\
\hline Xipamide & Epilacton X & $\begin{array}{c}\text { X } \\
\pm \text { S.D. } \\
\text { t } \\
F\end{array}$ & $\begin{array}{c}99.37 \\
\pm 0.85 \\
0.47 \\
3.91\end{array}$ & $\begin{array}{c}99.06 \\
\pm 1.05 \\
0.06 \\
2.58\end{array}$ & & $\begin{array}{l}99.01 \\
\pm 1.69\end{array}$ \\
\hline
\end{tabular}

${ }^{a}$ Six determinations were used for both reported and proposed methods.

* References 50, 51 and 52

The tabulated values of $\mathrm{t}$ and $\mathrm{F}$ at $95 \%$ confidence limit are $\mathrm{t}=2.23$ and $\mathrm{F}=5.05$

\section{Method II}

The interaction of most studied drugs, bendroflumethiazide, benzthiazide, chlorthalidone, clopamide, hydrochlorothiazide, indapamide and xipamide with potassium ferricyanide in acidic aqueous medium gave a bluish green coloured product with a strong absorption maximum at 720 $\mathrm{nm}$. The absorption spectrum of the interaction product of potassium ferricyanide with xipamide as a representative example for the studied drugs is shown in Figure 8.

\section{Factors affecting color develop- ment}

A preliminary investigation was carried out to determine the optimum conditions for the color formation for the studied drugs.

\section{Effect of sodium hydroxide concentration}

The absorption intensity increases by increasing concentration of sodium hydroxide and reaches its maximum value at $1.0 \mathrm{~mL}$ of $8.0 \mathrm{M}$ per $10 \mathrm{~mL}$ of final solution, after which no further increase was observed (Fig.9). 


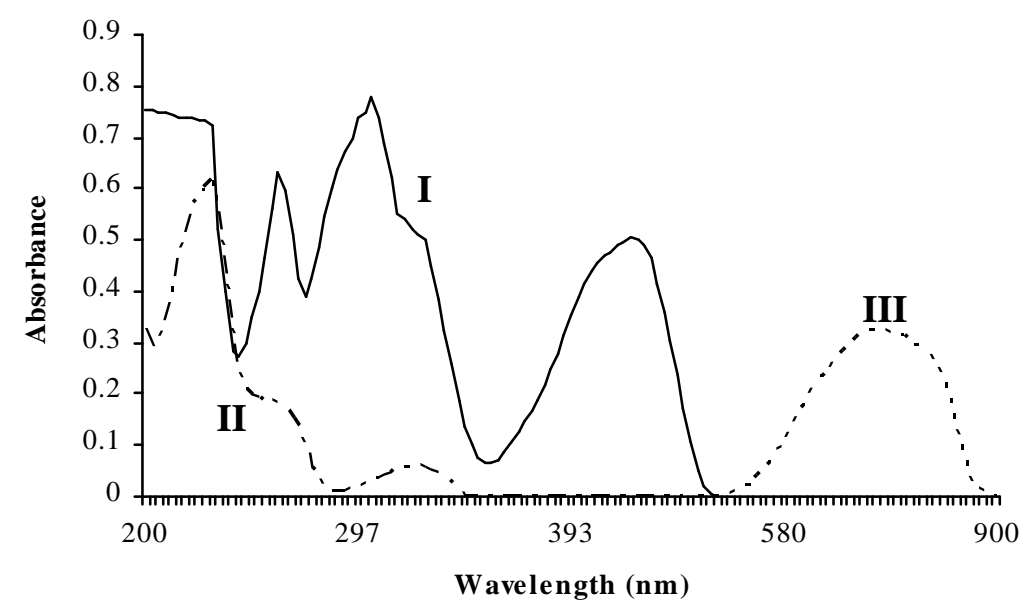

Fig. 8: Absorption spectra of $6 \mu \mathrm{g} / \mathrm{mL}$ potassium ferricyanide (I), $4 \mu \mathrm{g} / \mathrm{mL}$ xipamide (II) , and $0.8 \mu \mathrm{g} / \mathrm{mL}$ ferricyanide-drug complex (III).

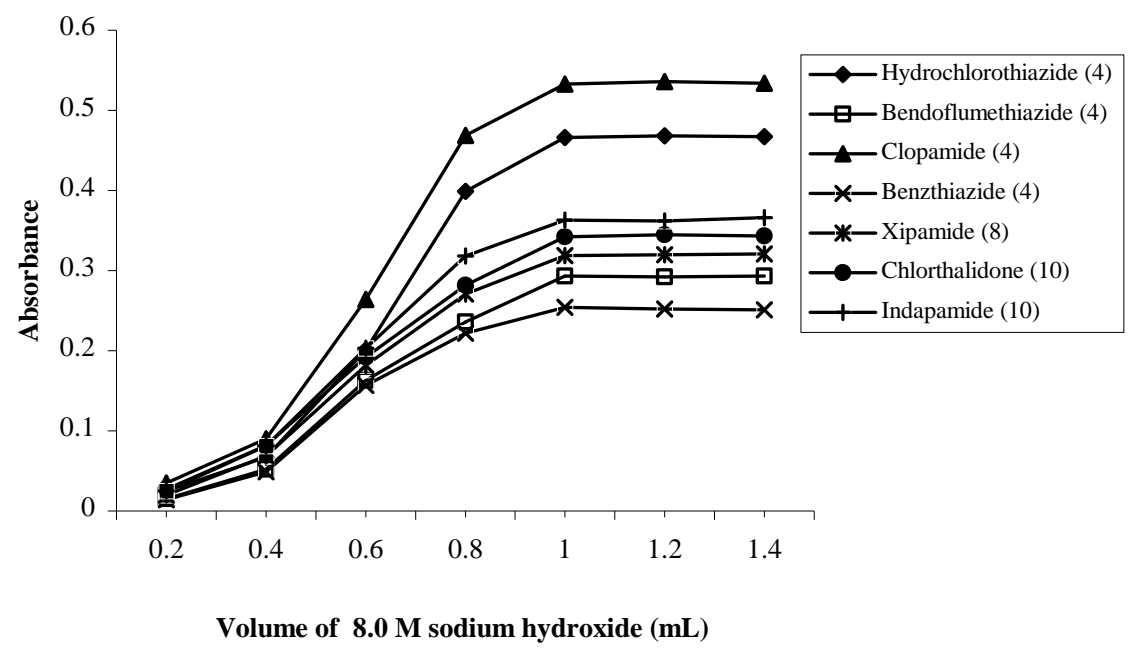

Fig. 9: Effect of sodium hydroxide concentration on the reaction between the investigated drugs $(\mu \mathrm{g} / \mathrm{ml})$ and potassium fericyanide reagent. 
Effect of potassium ferricyanide concentration

The absorption intensity increases by increasing concentration of potassium ferricyanide and reaches its maximum value at $1.0 \mathrm{~mL}$ of $0.01 \mathrm{M}$ per $10 \mathrm{~mL}$ of final solution, after which no further increase occurs. Higher concentrations are not recommended to avoid high absorption intensity of the reagent blank (Fig. 10).

\section{Effect of temperature}

The intensity of absorption of the coloured products increases on increasing temperature of heating with sodium hydroxide and potassium ferricyanide. The best result was at boiling point (Fig. 11).

\section{Effect of heating time}

The intensity of absorption of the coloured products increases on increasing time of heating on boiling water bath with sodium hydroxide and potassium ferricyanide. Optimum heating time was attained after 45 minutes for all of the studied drugs (Fig. 12).

Effect of hydrochloric acid concentration

The absorption intensity of the resulting products increases by increasing concentration of hydrochloric acid and reaches its maximum value at $1.0 \mathrm{~mL}$ of $8.0 \mathrm{M}$ per $10 \mathrm{~mL}$ of final solution, after<smiles>COO</smiles>

which the absorption intensity decreases. Higher concentrations are not recommended because the reaction completely depends upon hydrogen ion concentration (Fig. 13).

\section{Effect of development time}

The reaction time after neutralization was determined by following the color development at room temperature $\left(25 \pm 5^{\circ}\right)$ at 720 $\mathrm{nm}$. The reaction of potassium ferricyanide with each of the studied drugs exhibits higher color intensity when the reaction mixture was diluted to volume directly before measurement. Optimum reaction time was attained after 20 minutes for all of the studied drugs and the color remained stable for further 15 minutes for all of the studied drugs (Fig. 14).

\section{Stoichiometric study}

Using job's method of continuous variation, the molar ratio of potassium ferricyanide to each of the investigated drugs was 3:1.

\section{Suggested reaction mechanism}

It is well known that thiazide and thiazide-like diuretics hydrolyze easily specially in alkaline medium. ${ }^{53 \& 54}$ For instance, hydrochlorothiazide hydrolyzes to yield formaldehyde and 4-amino-6chlorobenzene-1,3-disulphonamide as shown in the following equation:

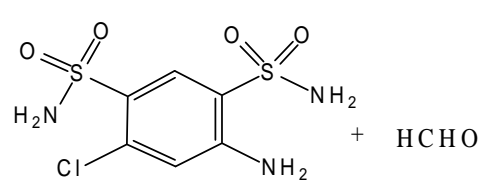




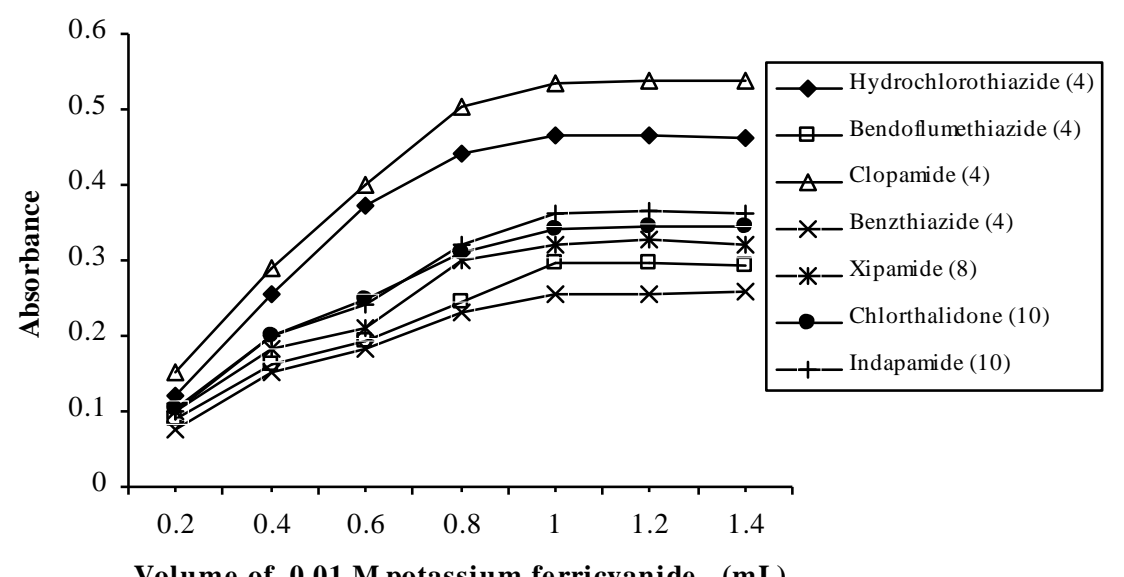

Volume of $0.01 \mathrm{M}$ potassium ferricyanide $(\mathrm{mL})$

Fig. 10: Effect of potassium ferricyanide concentration on the reaction between the investigated drugs $(\mu \mathrm{g} / \mathrm{ml})$ and potassium ferricyanide reagent.

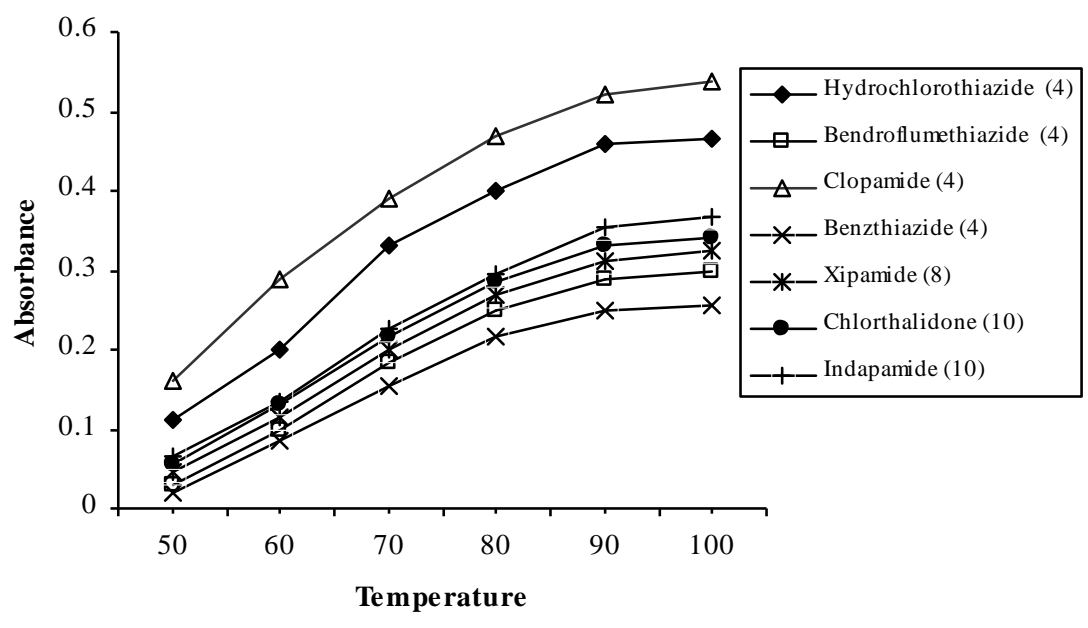

Fig. 11: Effect of temperature on the reaction between the investigated drugs $(\mu \mathrm{g} / \mathrm{ml})$ and potassium ferricyanide reagent. 


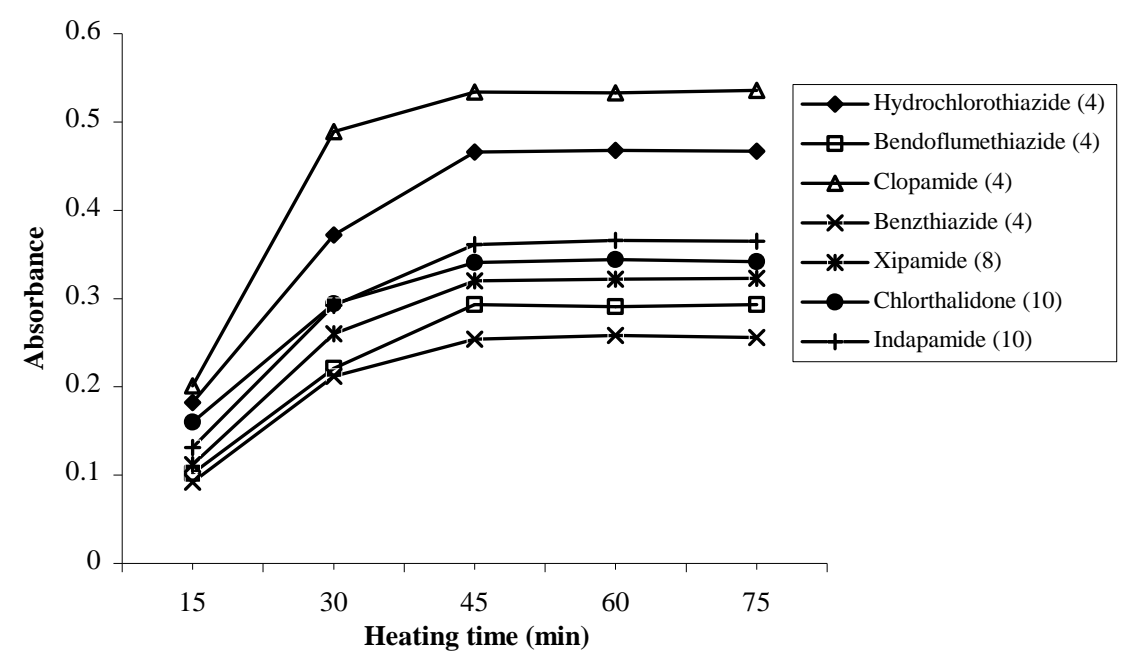

Fig. 12: Effect of heating time on the reaction between the investigated drugs $(\mu \mathrm{g} / \mathrm{ml})$ and potassium ferricyanide reagent.

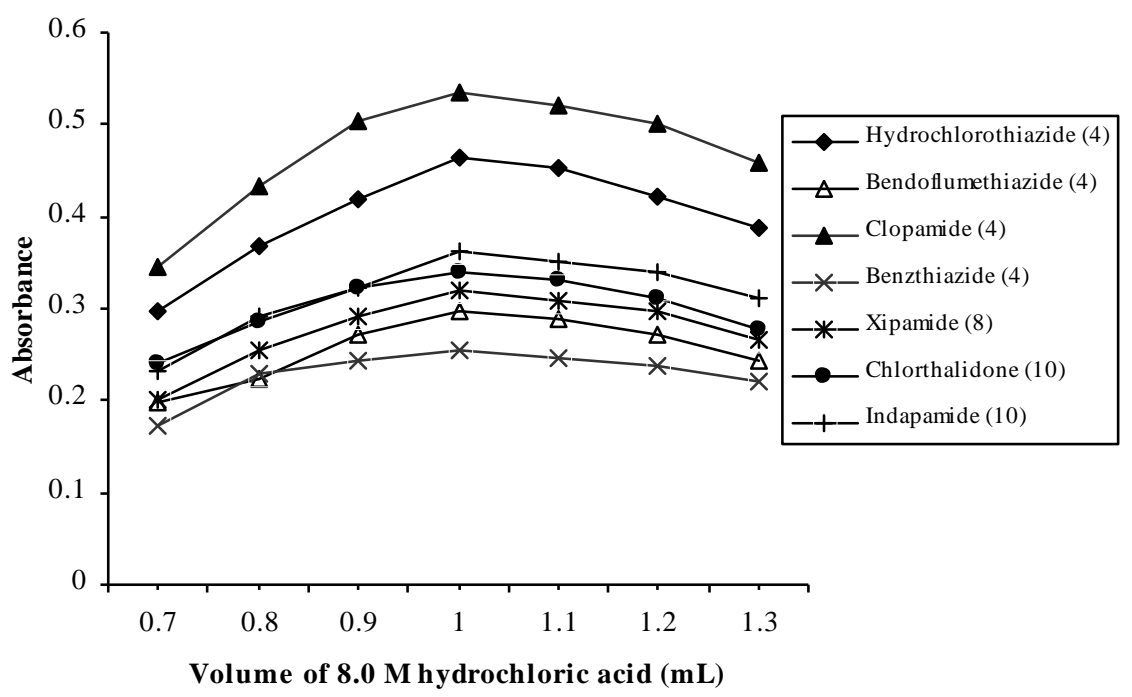

Fig. 13: Effect of hydrochloric acid concentration on the reaction between the investigated drugs $(\mu \mathrm{g} / \mathrm{ml})$ and potassium ferricyanide reagent. 


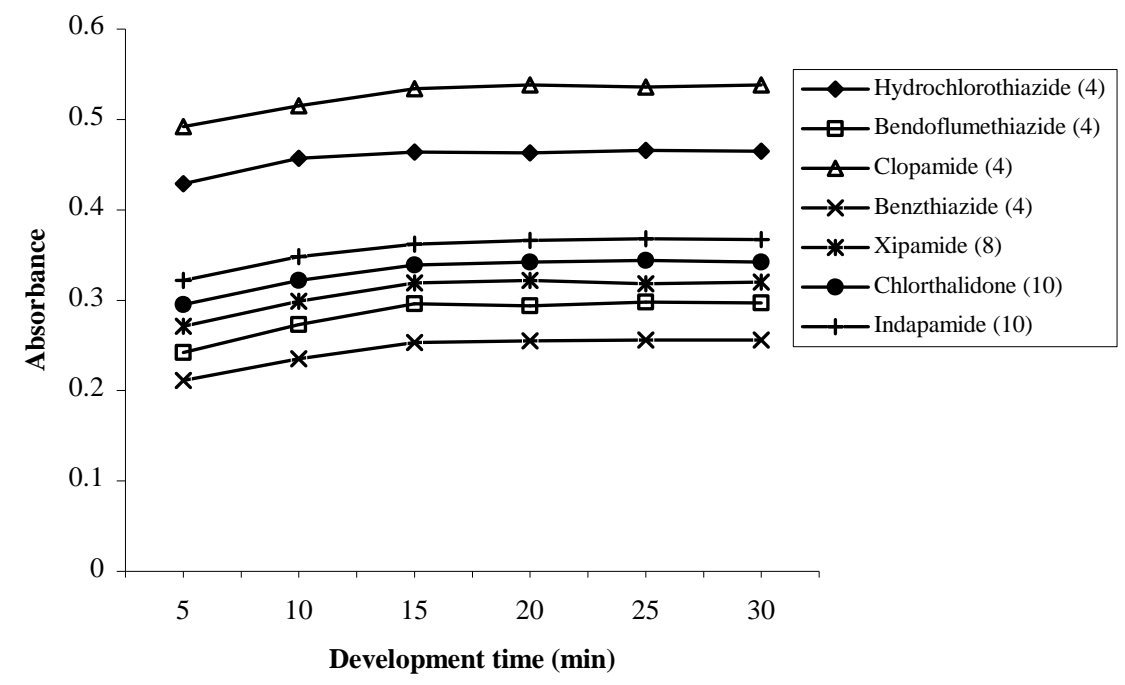

Fig. 14: Effect of development time on the reaction between the investigated drugs $(\mu \mathrm{g} / \mathrm{ml})$ and potassium ferricyanide reagent.

This is a reversible reaction and in the presence of ferricyanide that oxidizes formaldehyde, the reaction is drawn to the right and complete hydrolysis can occure, that is why ferricyanide is added with alkali during hydrolysis.<smiles>CS1(=O)=NCNc2cc(Cl)c(S(N)(=O)=O)cc21</smiles><smiles>[CH][N+](=C)c1cc(Cl)c(S(N)(=O)=O)cc1S(=N)(=O)[O-]</smiles>

$$
\begin{aligned}
& \mathrm{HCHO}+2\left[\mathrm{Fe}(\mathrm{CN})_{6}\right]^{3-}+\mathrm{H}_{2} \mathrm{O}= \\
& \mathrm{HCOOH}+2\left[\mathrm{Fe}(\mathrm{CN})_{6}\right]^{4-}+2 \mathrm{H}^{+}
\end{aligned}
$$

Ring opening can occur via another pathway: 
The two hydrolysis products can interact with each other as follows:

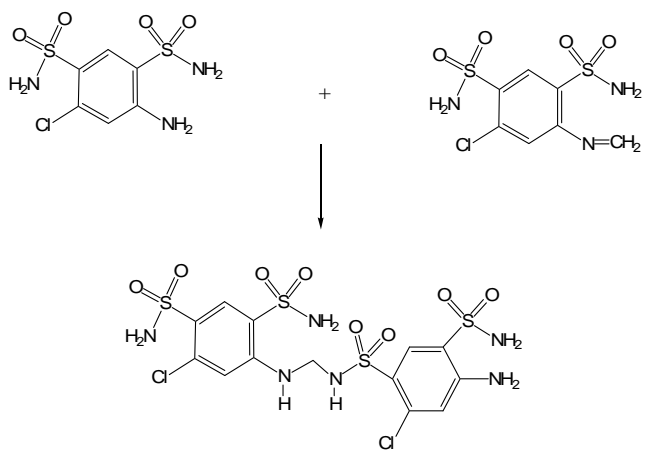

This addition product which is very similar to one of impurities found in hydrochlorothiazide (B.P) is oxidized under the influence of ferricyanide to the following dye, which is the chromogen being measured in the proposed assay:<smiles></smiles>

\section{Method III}

The investigated thiazide and thiazide-like diuretics have weak native fluorescence. However in this work, the investigated drugs (bendroflumethiazide, hydrochlorothiazide, hydroflumethiazide and clopamide) reacted with 4-chloro-7nitrobenzofurazan to give 4disubstituted amino-7-nitrobenzofurazan (yellow fluorescence) and can be measured at (excitation at $470 \mathrm{~nm}$ and emission at $535 \mathrm{~nm}$ ). Neither 4chloro-7-nitrobenzofurazan nor any of the studied drugs has excitation and emission at these wavelengths Figure (15) shows the excitation and emission spectra of the interaction product of hydrochlorothiazide as a representative example and 4-chloro7-nitrobenzofurazan.

\section{Factors affecting color develop- ment}

A preliminary investigation was carried out to determine the optimum conditions for the fluorophore formation for the studied drugs.

\section{Effect of heating temperature}

The relative fluorescence intensity of the resulting products increases on increasing temperature of heating of the drug with 4-chloro-7-nitrobenzofurazan to form yellow fluorescence. Optimum temperature was found to be $65^{\circ}$ for all of the studied drugs (Fig. 16).

\section{Effect of heating time}

The relative fluorescence intensity of the resulting products increases on increasing time of heating of the drug with 4-chloro-7-nitrobenzofurazan to form yellow fluorescence. Optimum heating time for all of the studied drugs was 45 minutes (Fig. 17).

\section{Effect of 4-chloro-7-nitrobenzo- furazan concentration}

The relative fluorescence intensity of the interaction products increases by increasing concentration of 4chloro-7-nitrobenzofurazan and reaches its maximum value at $1.0 \mathrm{~mL}$ after which no further increase was observed. Higher concentrations are not recommended (Fig. 18). 


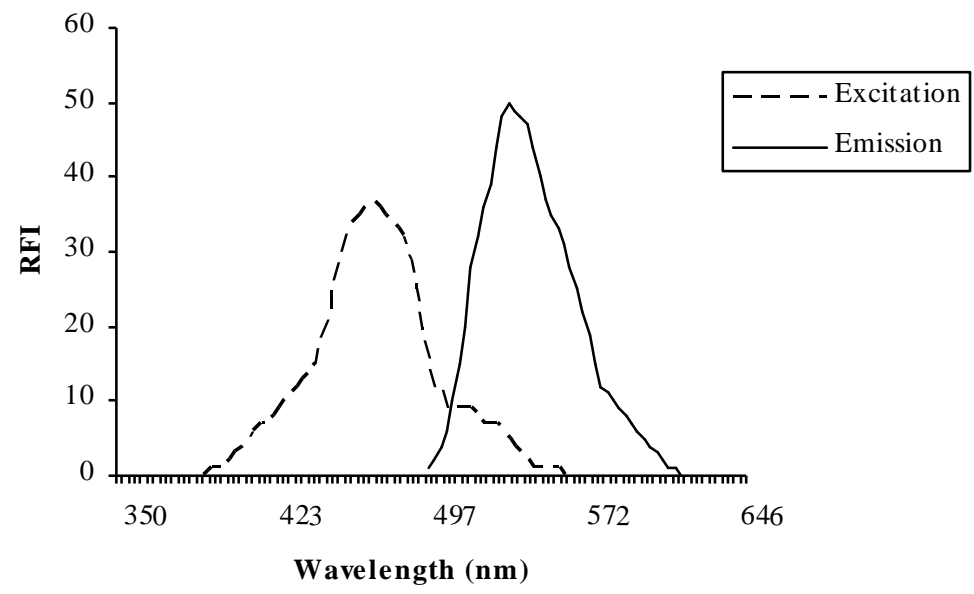

Fig. 15: Excitation and emission spectra of hydrochlorothiazide $(4 \mu \mathrm{g} / \mathrm{mL})-4-$ chloro7-nitrobenzofurazan condensation product in ethanol.

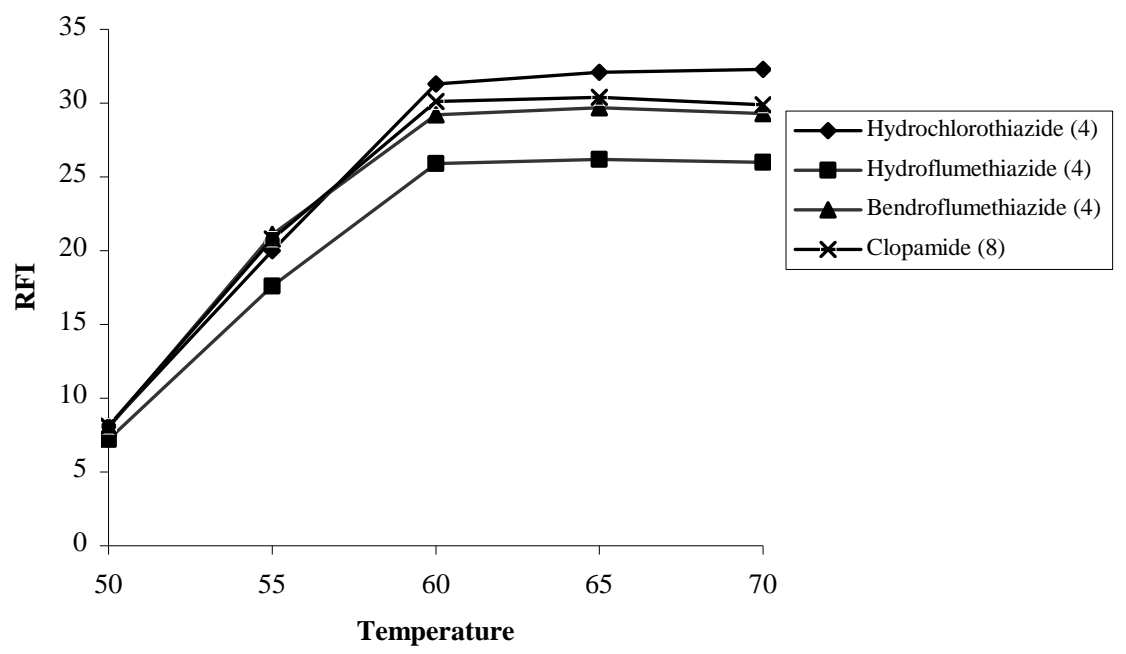

Fig. 16: Effect of temperature on the reaction between the studied drugs $(\mu \mathrm{g} / \mathrm{ml})$ and NBD-Cl in ethanol. 


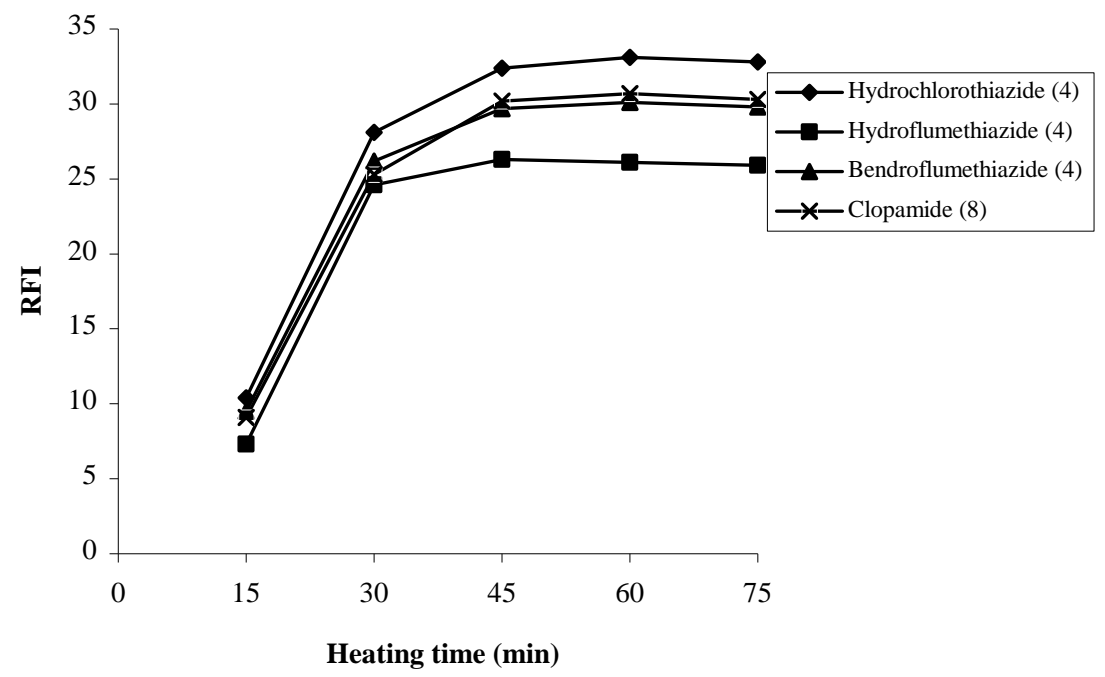

Fig. 17: Effect of heating time on the reaction between the studied drugs $(\mu \mathrm{g} / \mathrm{ml})$ and NBD-Cl in ethanol.

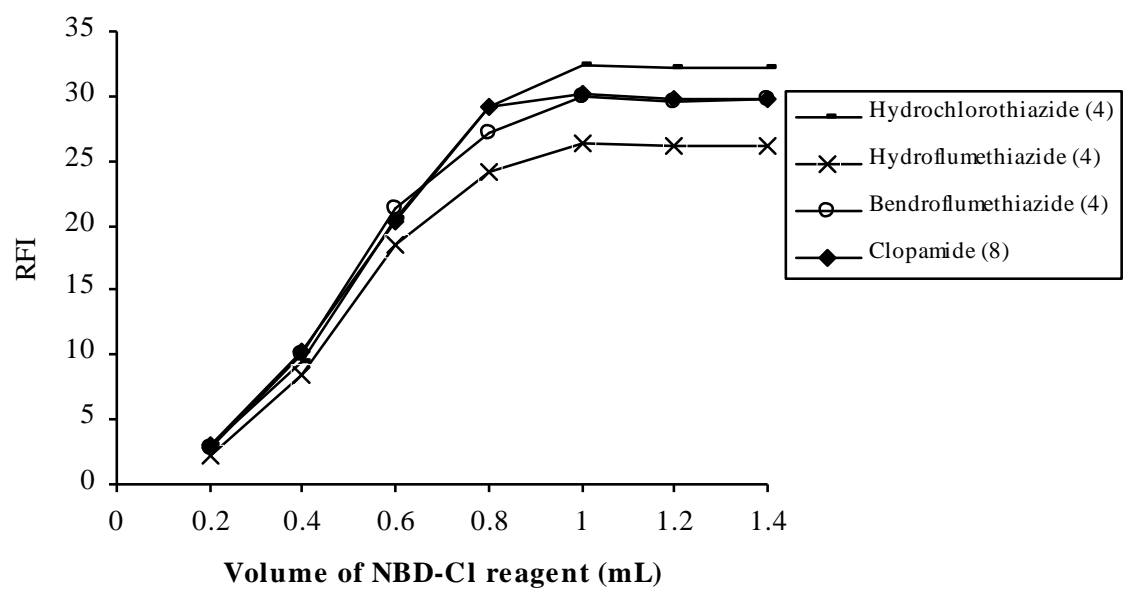

Fig. 18: Effect of NBD-Cl concentration on the reaction between the studied drugs $(\mu \mathrm{g} / \mathrm{ml})$ and NBD-Cl in ethanol. 


\section{Effect of diluting solvent}

The effect of various solvents of different polarities on the relative fluorescence intensities of the formed products was studied. Ethanol was found to be an ideal solvent for the formation of 4-disubstituted-7-nitrobenzofurazan. Methanol, dimethylformamide, dimethylsulphoxide and water gave lower relative fluorescence intensities.

\section{Stoichiometric study}

Using job's method of continuous variation, the molar ratio of 4-chloro7-nitrofurazan to each of the investigated drugs was 1:1.

\section{Suggested reaction mechanism}

The mechanism of reaction is based on the interaction between the secondary amine moiety of the chosen drugs and NBD-Cl to form yellow fluorescent products as shown in scheme II.

\section{Conclusion}

The proposed methods are simple, rapid and more sensitive than the official methods. Moreover, they can be applied to the quality control analysis of the studied drugs either in pure form or in combined dosage forms without interference. In addition to spectrophotometry and spectroflurimetry, infrared and ${ }^{1}$ HNMR spectroscopy could also be used to study the possible site of interaction between hydroxylamine and the investigated drugs.<smiles>[R8]c1cc2c(cc1S(N)(=O)=O)S(=O)(=O)NC([R3])N2</smiles><smiles>[R5]c1cc2c(cc1NS(=O)(=O)O)N(c1ccc([N+](=O)[O-])c3nonc13)C([R8])NS2(=O)=O</smiles>

… -

Yellow flourescent product

Scheme II: Suggested reaction mechanism for the reaction of studied drugs with NBD-Cl. 


\section{REFERENCES}

1- E. W. Manfred, "Burger's Medicinal Chemistry and Drug Discovery", $5^{\text {th }}$ Ed., New York, U.S.A., 1994, pp. 386-387.

2- J. W. Martin, and M. M. John, "Pharmacological Basis of Therapeutics", $10^{\text {th }}$ Ed., New York, U.S.A., 2002, pp. 773777.

3- A. W. David, and L. L. Thomas, "Foye's Principles of Medicinal Chemistry", $5^{\text {th }}$ Ed., Baltimore, Philadelphia, U.S.A., 2002, pp. 524-525.

4- The British Pharmacopoea, Her Majesty's Stationary Office, Londone, 1998.

5- The USP XXV, and NF 20, USP convention Inc., Twinbrook Parkway, Rockville, MD, U.S.A. (2002).

6- G. Camurri, A. Zaramella, J. Anal. Chem., 73, 3716 (2001).

7- M. J. Ruiz-Angel, R. D. Caballero, E. F. Simo-Alfonso and M. C. Garcia-AlvarezCoque, J. Chromatogr., A, 947, 31 (2002).

8- Y. Qin, S. Zhu, C. Wang, M. Zhao and S. Peng, Fenxi Ceshi Xuebao, 21, 85 (2002).

9- L. Amendola, C. Colamonici, M. Mazzarino and F. Botre, Anal. Chim. Acta, 475, 125 (2003).

10- K. Deventer, P. Van Eenoo and F. T. Delbeke, Comm. Mass Spec., 19, 90 (2005).

11- P. Garcia, M. A. Popot, F. Fournier and Y. Bonnaire, J. Mass Spec., 37, 940 (2002).
12- C. Talli, R. Ventura and J. Segura, Anal. Chimica Acta, 460, 289 (2002).

13- H. Mahgoub, Bull. Facu. Pharm., Cairo Univ., 41, 285 (2003).

14- N. F. Youssef, J. AOAC int. Sep-Oct., 86, 935 (2003).

15- M. Ciborowski, M. Icardo and M. Catala, J. Pharm. Biomed. Anal., 36, 693 (2004).

16- H. Siren and A. Karttunen, J. Chromatogr. B, 783, 113 (2003).

17- D. Corens, M. Carpentier, M. Schroven and L. Meerpoel, J. Chromatogr., A, 1056, 67 (2004).

18- I. Albero, V. rodenos, S. Garcia and C. Sanchez-Pedreno, J. Pharm. Biomed. Anal., 20:29, 299 (2002)

19- J. N. Latosinska, Mag. Res. Chem., 41, 395 (2003).

20- P. Campins-Falco, R. HerraezHernandez and A. SevillanoCabeza, J. Liq. Chromatogr., 16, 2571 (1993).

21- R. Herraez-Hernandez, P. Campins-Falco and A. SevillanoCabeza, ibid., 19, 403 (1996).

22- M. C. Ferraro, P. M. Castellano and T. S. Kaufman, J. Pharm. Biomed. Anal., 7:30, 1121 (2002).

23- V. Moreira and R. Moreau, J. Liq. Chromatogr., 28, 2753 (2005).

24- J. Beyer, A. Bierl, F. T. Peters and H. Maurer, Thera. Drug Moni., 27, 509 (2005).

25- K. Deventer, P. Van Eenoo and F. Delbeke, Rapid Comm. Mass Spec., 19, 90 (2005). 
26- R. G. Schlienger, M. E. Kraenzlin, S. S. Jick and C. R. Meier, J. Amer. Med.l Assoc., 292, 1326 (2005).

27- T. Takubo, H. Okada, M. Ishii, K. Hara, and Y. Ishii, J. Chromatogr., B, 806, 199 (2004).

28- D. Ivanovic, M. Medenica, A. Malenovic and B. Jancic, Acc. Quali. Ass., 9, 76 (2004).

29- H. Salem, M. El-Maamli, M. ElSadek and A. Aboul-Kheir, Spec. Lett., 24, 451 (1991).

30- A. Mohamed and H. Salem, Anal. Bio. Anal., (2005).

31- J. Ouyang, W. R. G. Baeyens, J. Delanghe, G. Van Der Weken, W. Van Daele, D. De Keukeleire and A. M. Garcia Campana, Anal. Chimica Acta, 386, 257 (1999).

32- W. Fang, W. Xie, J. Y.-K. Hsieh and B. K. Matuszewski, J. f Liqu. Chroma., 28, 2681 (2005).

33- K. Deventer, P. Van Eenoo and F. T. Delbeke, Rapid Comm. Mass Spec., 19, 90 (2005).

34- A. I. Mohamed, S. A. Hussein, H. M. Abdel-Wadood, Bull. Pharm. Sci., Assiut University, 26, 5 (2003).

35- L. Amendola, C. Colamonici, M. Mazzarino and F. Botre, Anal. Chimica Acta, 475, 125 (2003).

36- X. Gao, J. Chen, N. Mei, W. Tao, W. Jiang and X. Jiang, Chromatographia, $\quad 61, \quad 581$ (2005).
37- X. Suo, Y. Deng and A. Hao, J. Chromatogr., B, 819, 191 (2005).

38- K. Deventer, P. Van Eenoo and F. Delbeke, Rapid Comm. Mass Spec., 19, 90 (2005).

39- C. Rodriguez, J. Barciela, S. Garcia, C. Herrero and M. Pena, J. AOAC Int., 88, 1148 (2005).

40- J. Tang, J. Li, J. Sun, J. Yin and Z. He, Pharmazie, 60, 819 (2005).

41- W. Luo, S. Fenxi, 23, 69 (2004).

42- F. Nie, J. Lu and W. Niu, Anal. Chimica Acta, 545, 129 (2005).

43- Y. Kim, K. Han, K. Paeng and W. Lee, Rapid Comm. Mass Spec., 18, 2780 (2004).

44- J. Beyer and A. Bierl, Ther. Drug Mon., 27, 509 (2005).

45- K. Deventer, P. Van Eenoo and F. T. Delbeke, Rapid Comm. Mass Spec., 19, 90 (2005).

46- M. Y. Salem, H. A. Merey, A. El Bayoumi and B. A. El Zeany, Bull. Fac. Pharm., Cairo University, 41, 27 (2003).

47- P. C. Meier and R. E. Zund, "Statistical Methods in Analytical Chemistry", John Wieley \& Sons Inc., USA (1995).

48- P. Job, Ann. Chem., 16, 97 (1936).

49- D. T. Sawer, W. R. Heinman and J. M. Beebe, "Chemistry Experiments for Instrumental Methods", John Wiley \& Sons Inc., USA (1984). 
50- M. Macher and R. Wentersteiger, J. Chromatogr. A. Aug., 709, 257 (1995).

51- E. Bonet-Domingo, M. J. Median-Hernandez, G. RamisRamos and M. C. GarciaAlvarezcoque, J. Chromatogr., B, 120, 189 (1992).

52- E. Gonzalez, A. Becerra and J. Laserna, ibid., 687, 145 (1996).
53- A. C. Kenneth, L. A. Gordan and J. Valentino, "Stability of Pharmaceuticals", Stella John Wieley and Sons, New York, U.S.A. (1972).

54- J. A. Mollica, C. R. Rehm, J. B. Smith and H. K. Govan, J. Pharm. Sci., 60, 1380 (1971). 